\title{
Logopaedics as an Interdisciplinary Science in the Eyes of Speech Therapists Preliminary Research Results
}

Logopedia jako nauka interdyscyplinarna w oczach logopedów Wstępne wyniki badań

Keywords: logopaedics as a science, interdisciplinary character of logopaedics, specific methods of diagnosis and speech therapy

Słowa kluczowe: logopedia jako nauka, interdyscyplinarność logopedii, specyficzne metody diagnozy i terapii logopedycznej

\section{Introduction}

The interdisciplinary character of logopaedics has become a popular topic in the last year, which is reflected by the fact that three all-Poland conferences devoted to logopaedics took place in 2019: a scientific conference entitled "Interdyscyplinarne aspekty diagnozy i terapii logopedycznej" (Interdisciplinary aspects of diagnosis and speech therapy) in Lodz organized by the University of Lodz on 19 October; 16th all-Poland conference on logopaedics: "Interdyscyplinarność w logopedii - konieczność czy nadmiar?" [Interdisciplinarity in logopaedics: necessity or excess?] held by the Maria Grzegorzewska Academy of Special Education in Warsaw, the Speech Therapy Division of the Society for Language Culture, Speech Therapy Centre of the Institute of Applied Polish Studies at Warsaw University on 26-27 October; 10th all-Poland logopaedic conference "Logopedia w teorii i praktyce. Interdyscyplinarne aspekty diagnozy i terapii logopedycznej" [Logopaedics in theory and practice. Interdisciplinary aspects of diagnosis and speech therapy] organized by the Polish

\footnotetext{
* University of Lodz, Faculty of Philology, Institute of Polish Philology and Logopaedics, Department of Polish Dialectology and Logopaedics, 171/173 Pomorska street, 90-236 Łódź, e-mail: danuta@pluta-wojciechowska.eu, ORCID: https://orcid.org/0000-0003-0425-6006.
} 
Logopaedic Society, Division of Silesia, in collaboration with St. Barbara Provincial Specialist Hospital no. 5 in Sosnowiec, Trauma Centre on 16 November.

What is the reason for the popularity of topic connected with the interdisciplinary character of logopaedics which was discussed during the scientific meetings? Is it a fad or a necessity? Or perhaps undertaking the topic of cooperation with other specialists is caused by certain confusion and ambiguity connected with unjustified usage of some methods of diagnosis and therapy which are foreign to logopaedics by speech therapists? It is possible that speech therapists feel slightly lost as their day-to-day work with the patient with speech disorders definitely requires cooperation with doctors. Practice shows that this is not always easy since, as it may be presumed, some doctors do not understand what the job of speech therapists involves (adopting a different perspective on logopaedic phenomena) and, not having relevant competences, fail to follow recommendations or requests of speech therapists directed to doctors. And obviously doctors are not speech therapists. As it will be pointed out later in the article, Polish logopaedics, if personified, should be concerned about the state of knowledge on the indisciplinarity of some people who work as speech therapists. I fear, and I wish I was wrong, that the alarming phenomenon described in this paper is far more likely to be on the increase rather than decrease in the future.

The subject of analysis of this study is the interdisciplinary character of logopaedics. This problem only seemingly appears to be simple, particularly in the face of results of survey research concerning the practical accomplishment of the postulate of interdisciplinarity as there is some doubt connected with different understanding of this feature of logopaedics. In the introduction the article presents the subject of logopaedics and its place among other sciences as well as the essence of interdisciplinarity as a phenomenon connected with combining knowledge. The paper also discusses some threats connected with this process. Its subsequent part includes results of preliminary questionnaire survey which point to different understanding of interdisciplinarity by speech therapists. This is not a favourable phenomenon in the face of constituting of logopaedics as an independent science but also with regard to the well-being of patients with speech disorders.

It was my meeting with a group of speech therapists in one of the Polish cities that became the immediate reason for conducting research into the state of knowledge on logopaedics, its interdisciplinarity, the specific character of diagnosis and therapy methods used in logopaedics. The participants of the lecture gave me an account of the following story. One speech therapist who took part in a several-hour training course on otoscopic examination decided to use this tool to examine the hearing of a small child. Regrettably, her inability to use this tool correctly resulted in puncturing the drum membrane of the small patient. The dissatisfied parents of the child decided to carry out an investigation into this case in court.

Moved by the story related by many speech therapists I decided to carry out research aimed at analysing the knowledge of speech therapists on their understanding 
of the specific character of methods used in logopaedics during diagnosis and therapy as well as their understanding of the gist of diagnosis, therapy, interdisciplinarity, collaboration with other specialists who help people with speech disorders. The preliminary summary of the research results is a source of concern and encourages reflection connected with the level of speech therapy education, including postgraduate training.

\section{Conditionings of considerations on the place of logopaedics among other disciplines}

So as to understand correctly the place of logopaedics among other sciences and define the essence of interdisciplinarity, it is necessary to recall the process of giving rise to and isolating scientific disciplines. One of the conditions for emerging a new discipline is a clearly defined subject of research which is original and different from those of other disciplines. This is in line with the stance of Stanisław Grabias, according to whom logopaedics meets this condition [Grabias, 1997; 2008; 2012].

During the process of shaping and ordering knowledge over time one may observe the process of its division, the effect of which is separation of individual disciplines. This phenomenon is accompanied by a process in the opposite direction, namely combining knowledge, which is reflected in, for instance, interdisciplinarity. One advantage of knowledge division is that generating knowledge becomes more efficient as researchers concentrate on a narrower problem, which allows to achieve a deeper insight into the given issue. Drawbacks, in turn, include the introduction of separate methods and terminology, which makes contacts between the representatives of individual disciplines more difficult. In such a paradigm many issues are not solved, however, within narrow perspectives of relevant individual specializations or fields of research, which as a result leads to realization of the postulate of combining knowledge e.g. in the form of interdisciplinarity.

Combining knowledge assumes a number of forms, namely multidisciplinarity, interdisciplinarity and transdisciplinarity [Kita, 2012; Michalik, 2015]. Each of these paradigms involves a kind of combining knowledge - notions and concepts from different disciplines with regard to the research topic. There are, however, notable differences with regard to the ways of consolidating knowledge.

Hence in the case multidisciplinary approach the discussed research question is analyzed with the use of methods typical of individual disciplines and subsequently research results are juxtaposed with each other considering the sum of individual final results. This may be compared to a multi-author monography on the given subject. Individual authors analyze the phenomenon in question, using certain methods which are typical of the given discipline. Multidisciplinarity accounts for, therefore, the confrontation of different perspectives but with no general overview. 
Integration of knowledge is left to the reader who uses accomplished and compiled research of individual disciplines.

Interdisciplinarity assumes drawing on the output of other disciplines, and research leads to the transfer and fusion (of notions, methods, data) between two or several disciplines. Interdisciplinarity allows to overcome the limitations of certain disciplines where specialists analyze the given phenomenon, using their own methodology. This paradigm of combining knowledge "breaks down border walls" between disciplines, showing a new context yet it does not lead to reformulating the scientific field.

Transdisciplinarity, in turn, seems to be a project in logopaedics [Michalik, 2015]. The rudimentary difference between interdiscipliarity and transdisciplinarity concerns the research field which in the case of transdisciplinarity leads to its redefinition. The research carried out with the use of this paradigm results in creating a coherent picture of the researched area, preserving the narration and methods of individual disciplines [Kita, 2012; Michalik, 2015].

\section{Between linguistics and medicine as well as pedagogy and psychology}

Taking into consideration the epistemological space, logopaedics situates itself between linguistics, medicine as well as pedagogy and psychology. It fills the void between these sciences with certain original and integrating knowledge on speech and its disorders. It is not linear knowledge but it synthetizes findings from different branches of knowledge. Logopaedics also creates its own knowledge unparalleled in other disciplines. It concerns the diagnosis and therapy of speech disorders. This is connected with the subject of logopaedics defined as biological conditioning of language and language behaviours [Grabias, 2012].
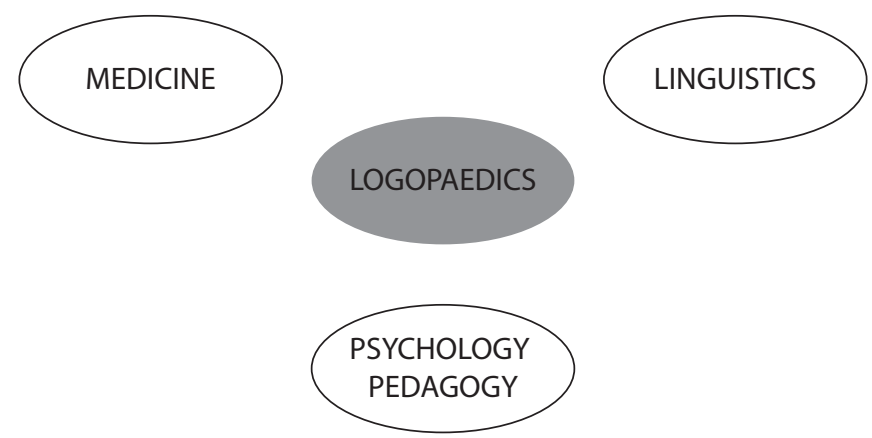

Picture 1. The place of logopaedics in the epistemological space

Source: own study. 
The research subject of logopaedics defined in this way imposes multiple perspectives of description and interpretation of the diagnosed dysfunctions of language and language behaviours. Logopaedics not only is but has to be interdisciplinary. This is due to the fact that language is a multi-aspect phenomenon which requires analysis from different perspectives: linguistic, medical, social and psychological as well as, importantly, that of logopaedics. Hence going beyond INTRAdisciplinary boundaries in logopaedics is essential. Where is, though, the border of "using the achievements of other disciplines"?

Correlations of logopaedics with other disciplines have already been subject of analysis by, for instance, Stanisław Grabias [1997; 2012], Edward Łuczyński [2011], Mirosław Michalik [2015] and Józef Porayski-Pomsta [2013] and Danuta Pluta-Wojciechowska [2019]. Tables 1-3 include useful breakdowns of data which make it easier to notice the originality of the research subject of logopaedics as well as define the role of linguistics and medicine in the course of speech therapy procedure. Table 1 shows the subject of research of linguistics, research and medicine with the use of the definition which may be found in Uniwersalny stownik jezzyka polskiego [The Universal Dictionary of the Polish Language] edited by Stanisław Dubisz [2004] as well as the approach to the subject of logopaedics by Stanisław Grabias [2012]. The definition of the subjects of logopaedics is complemented (see Table 1) by the procedures of proceedings described by the author [Grabias, 1997; 2012; 2015].

Table 1. Linguistics, logopaedics and medicine: the subject of research

\begin{tabular}{|l|l|l|}
\hline \multicolumn{1}{|c|}{ Linguistics } & \multicolumn{1}{|c|}{ Logopaedics } & \multicolumn{1}{c|}{ Medicine } \\
\hline $\begin{array}{l}\text { Scientific study on speech } \\
\text { as a tool of human } \\
\text { communication, its structure, } \\
\text { functions and development }\end{array}$ & $\begin{array}{l}\text { Science on the biological } \\
\text { conditionings of speech and } \\
\text { speech behaviours recognized } \\
\text { in the course of diagnosis } \\
\text { of signs and symptoms used } \\
\text { to programme and conduct } \\
\text { therapy aimed at eliminating } \\
\text { the disorders or lowering their } \\
\text { intensity }\end{array}$ & $\begin{array}{l}\text { Science on human health and } \\
\text { diseases as well as on ways } \\
\text { on treating them; also: the art } \\
\text { of treating the ill and preventing } \\
\text { diseases }\end{array}$ \\
\hline
\end{tabular}

Source: own study, Pluta-Wojciechowska, 2019, p. 24.

Mirosław Michalik is right in saying that "Bearing in mind that logopaedics has been dynamically growing over the last few decades redefining from time to time the subject of its research, it should not be excluded that the definition currently in force may be only temporary" [Michalik, 2015, pp. 33-34]. The subject of research on logopaedics is not only original, unparalleled in other sciences but it also brings new organization of epistemological space as logopaedics bridges the gap between linguistics and medicine as well as pedagogy and psychology [cf. Pluta-Wojciechowska, 2019, pp. 21-34]. 
Analyzing the subject of logopaedics, it is worth noting the relation between biological conditionings of language and language behaviours and symptoms of speech disorders, which are shown in Table 2. Detecting this relationship is not only the essence of logopaedics diagnosis but also a secret of effective therapy. Discovering the connections between the symptom of speech disorders and their causes requires knowledge which is non-linear but synthetizing reports from different disciplines. This knowledge is connected with logopaedics [Grabias, 2012; Pluta-Wojciechowska, 2019].

Commenting on the importance of both linguistic and medical knowledge in the context of speech disorders, it may be concluded that logopaedics does not only benefit from the knowledge of the indicated disciplines but also creates its own original knowledge since (cf. Tables 2, 3):

- in the context of linguistics: it does not suffice to know the language (as a two-class system) but it is also necessary to know how to analyze it in a way allowing for a description of disorders and asking questions about their causes as well as programming and running a therapy;

- in the context of medicine: it does not suffice to know the construction of the human body, symptoms of diseases as well as methods of their treatment but it is also necessary to know in what way the state of health affects constituting speech disorders;

- in the context of assistance connected with eliminating or lessening the intensity of a speech disorder: in order to conduct a therapy it is necessary to carry out a symptom-cause diagnosis and know the mechanisms of speech development both in the norm and pathology, it is necessary to know the methodology of speech therapy procedure in the case of the given disorders.

Table 2. The subject of logopaedics

Biological conditionings of language and language behaviours
Symptoms of speech disorders

Source: own study.

Summing up the above considerations it may be concluded that logopaedics:

- has the knowledge on the ways of examining and describing speech and provides speech therapists with specific skills allowing to conduct a diagnosis and therapy of speech disorders in the course of their education;

- interprets (putting forward hypotheses and verifying them through e.g. medical examinations) speech disorders, using the achievements of medicine and psychology;

- it draws on linguistics and medicine enriching them as it uses the knowledge on the structure of the language as a two-class system as well as medical knowledge concerning the state of human organism and possibilities of treatment 
with the use medical methods in order to eliminate diseases and dysfunctions detrimental to speech development;

- creates integrating knowledge on speech disorders;

- the speech therapist plans, programmes and conducts therapy, which is not encountered in linguistics or medicine even though speech therapists may work in medical and educational centres.

Table 3. Tasks of linguistics, logopaedics and medicine and speech disorders

\begin{tabular}{|c|c|c|}
\hline Linguistics & Logopaedics & Medicine \\
\hline $\begin{array}{l}\text { Providing linguistic tools of the } \\
\text { description of language and } \\
\text { language behaviours, or the } \\
\text { knowledge on the phonemic } \\
\text { and phonetic systems as well } \\
\text { as morphological and syntactic } \\
\text { ones }\end{array}$ & $\begin{array}{l}\text { The use of logopaedic } \\
\text { methodology of analysis and } \\
\text { description of language and } \\
\text { language behaviours which } \\
\text { are not in accordance with the } \\
\text { linguistic norm, the logopedic } \\
\text { interpretation of speech } \\
\text { disorders in the context } \\
\text { of biological and psycho-social } \\
\text { conditionings } \\
\text { Programming and conducting } \\
\text { speech therapy }\end{array}$ & $\begin{array}{l}\text { Examination and description } \\
\text { of biological conditionings } \\
\text { of language and language } \\
\text { behaviours, in which the speech } \\
\text { therapist sees the causes } \\
\text { of speech disorders, treating the } \\
\text { human body }\end{array}$ \\
\hline
\end{tabular}

Source: own study.

I think I will not depart from the truth if I say that logopaedics stems from the insufficiency of linguistic and medical as well as psychological and pedagogical approaches to speech disorders, which may be found in the original subject of its research and the tasks accomplished during the speech therapy procedure. Yet this is not all as using the output of both linguistics and medicine, logopaedics at the same time complements the paradigms functioning in these disciplines. It enriches linguistics and medicine since it analyses language and behaviours in impaired discourse and it also describes the impact of some diseases on speech. Logopaedics is not, therefore, a sum of medical and linguistic knowledge. Edward Łuczyński wrote articulately about the relations of logopaedics and linguistics: "[...] logopaedics does not only use the knowledge about language but it also (or maybe even above all) co-creates this knowledge" [Łuczyński, 2011, p. 8, emphasis D.P.-W.].

In turn, the relations of pedagogy and psychology with logopaedics refer to the common space connected with "providing people with help" as well as the use in logopaedics of some methods and principles formulated by, for instance, didactics, theory of education or developmental psychology, clinical psychology, cognitive psychology or psychotherapy. During the diagnosis the speech therapist uses data on the psychomotor development of the patient, his emotional and social states which may to a different degree modify the patient's social and linguistic functioning. Apart from that, during both diagnosis and therapy the speech therapist uses specific 
methods such as audiovisual sound assessment, language programming, sound elicitation, exercises of the tongue for the purposes of eliciting speech sounds, analysis of language and communicative competence, etc.

Hence the gap between linguistics and medicine as well as pedagogy and psychology is bridged by the original logopaedic methodology as well as the methodology of analysis and description of language and language behaviours as well as their logopedic interpretation in the context of biological and psychological and social conditionings. Logopaedics is an original branch of science rather than a sum of linguistic and medical as well as psychological and pedagogical knowledge. Due to the subject of its research logopaedics has to be interdisciplinary, there is no other possibility. In addition, logopaedics is distinguished by programming and conducting therapy on the basis of a diagnosis of heuristic profile, often initially of preliminary character [Pluta-Wojciechowska, 2019, pp. 21-37].

\section{Threats related to the interdisciplinarity of logopaedics}

The word interdisciplinary is defined in Słownik jezzyka polskiego [The Dictionary of the Polish Language] as: "1. concerning two or more scientific disciplines, 2. using the output of several sciences, 3 . comprised of scientists representing different branches of knowledge" [Dubisz, 2004].

It is worth paying attention to the phrase "using the output of several sciences". Going beyond the meaning of this word may lead to predatory interdisciplinarity which is referred to by Leszek Koczanowicz with regard to humanistic and social sciences [Koczanowicz, 2011]. Misinterpreting the postulate of interdisciplinarity may also give rise to blurring of boundaries between different disciplines, e.g. logopaedics and pedagogy or logopaedics and medicine.

The essence of interdisciplinarity may be expressed in the following way: common meeting of different disciplines may and should result in a new outlook on the patient with speech disorders provided that different methodologies are respected. Does this happen in Polish logopaedics nowadays? Do speech therapists never cross the borders marked by the scope of the term "interdisciplinarity"? The conducted research arouses anxiety connected with crossing the borders of logopaedic methodology by some speech disorder specialists, which will be dealt with in the following chapter. This is not a favourable phenomenon either from the point of view of the development of logopaedics as a science and a practical activity or from that of the patient's wellbeing. 


\section{Preliminary results of the research of the project "Logopaedics in the eyes of speech therapists"}

The aim of the conducted research is to get to know the state of knowledge of active speech therapists on logopaedics as both a science and a practical activity. A survey containing 15 questions which were both open and closed was used in the course of the research. An analysis of preliminary and selected research results is presented below with reference to understanding the notion of interdisciplinarity by speech therapists as well as their knowledge on the specificity of diagnosis methods and speech therapy. Forty speech therapists from different regions of Poland took part in the research. The characteristics of the group is presented in Table 4 .

Table 4. Characteristics of the analyzed group of speech therapists

\begin{tabular}{|c|c|c|c|c|}
\hline Analysis categories & Detailed data & $\begin{array}{c}\text { Group I } \\
\text { - up to } 5 \text { years } \\
\text { of work } \\
\text { experience }\end{array}$ & $\begin{array}{c}\text { Group II - } 10 \text { years } \\
\text { or more of work } \\
\text { experience }\end{array}$ & Total \\
\hline \multirow{3}{*}{$\begin{array}{l}\text { Qualifications for the } \\
\text { profession of speech } \\
\text { therapist }\end{array}$} & $\begin{array}{l}\text { First-cycle and/or second- } \\
\text { cycle degree programme }\end{array}$ & 4 & 4 & 8 \\
\hline & Postgraduate studies & 16 & 15 & 31 \\
\hline & $\begin{array}{l}\text { Long-cycle Master's } \\
\text { degree programme }\end{array}$ & 0 & 1 & 1 \\
\hline
\end{tabular}

Source: own study based on research.

In turn, Table 5 presents results of analysis of the answer to the question "What does it mean that logopaedics is an interdisciplinary discipline?". The question was open, which means that summarizing the results required ordering the obtained answers and putting them into the distinguished subcategories which were established after analyzing all the answers of the respondents. It is possible that a different categorization of respondents' answers will be presented in another paper in the course of subsequent analysis. The current analysis allows to conclude that speech therapists understand the interdisciplinarity of logopaedics in disparate ways, and attention is drawn to such answers as: "It takes knowledge from many scientific disciplines, combining it into a separate discipline", "Logopaedics is "inserted" into other medical and linguistic sciences", "It combines other sciences which permeate each other" [emphasis D.P.-W.]. These answers allow to presume that some speech therapists do not see clearly enough the role of logopaedics in the examination, description and interpretation of speech disorders.

The subsequent question concerned the specificity of methods of diagnosis and therapy in logopaedics. The results of the analysis are presented in Table 6. It shows that over half of respondents think that logopaedics has specific methods of diagnosis and therapy whereas the rest are of a different opinion or they have no opinion 
on this topic or they fail to answer this question. The research results inspire reflection on the understanding by speech therapists of the gist of their profession, including its interdisciplinarity.

Table 5. Results of the analysis of answers to the question: "What does it mean that logopaedics is an interdisciplinary discipline?"

\begin{tabular}{|l|c|c|c|}
\hline \multicolumn{1}{|c|}{ Types of answers } & Group I & Group II & In total \\
\hline No answer & 2 & 0 & 2 \\
\hline $\begin{array}{l}\text { It takes knowledge from many scientific disciplines, combining it into } \\
\text { a separate discipline }\end{array}$ & 6 & 1 & 7 \\
\hline It uses knowledge from different disciplines & 0 & 13 & 13 \\
\hline Knowledge from different sciences coincides in logopaedics & 1 & 0 & 1 \\
\hline It cooperates with others & 4 & 9 & 13 \\
\hline Logopaedics is "inserted" into other medical and linguistic sciences & 1 & 0 & 1 \\
\hline It combines other sciences which permeate each other & 6 & 1 & 7 \\
\hline $\begin{array}{l}\text { We need specialists who would look at the patient "from their own } \\
\text { perspective" }\end{array}$ & 0 & 1 & 1 \\
\hline
\end{tabular}

Source: own study based on research.

Table 6. Results of research concerning the specificity of diagnostic methods and logopaedics

\begin{tabular}{|l|l|c|c|c|}
\hline \multicolumn{1}{|c|}{ Analysis categories } & Response types & Group I & Group II & In total \\
\hline \multirow{2}{*}{$\begin{array}{l}\text { Does logopaedics have any specific diagnostic } \\
\text { methods in your opinion? }\end{array}$} & No answer & 1 & 1 & 2 \\
\cline { 2 - 5 } & Yes & 9 & 13 & 22 \\
\cline { 2 - 5 } & No & 6 & 2 & 8 \\
\cline { 2 - 5 } & I have no opinion & 4 & 4 & 8 \\
\hline \multirow{3}{*}{$\begin{array}{l}\text { Does logopaedics have any specific therapy } \\
\text { methods in your opinion? }\end{array}$} & No answer & 1 & 5 & 6 \\
\cline { 2 - 5 } & Yes & 15 & 11 & 26 \\
\cline { 2 - 5 } & No & 2 & 2 & 4 \\
\cline { 2 - 5 } & I have no opinion & 2 & 2 & 4 \\
\hline
\end{tabular}

Source: own study based on research.

The subsequent questionnaire questions were connected with a request to enumerate example speech therapy methods specific of diagnosis and therapy. The research results are presented in Tables 7 and 8 . The question with regard to the methods of diagnosis was: "If speech therapy has any specific methods of diagnosis, please enumerate some of them". As it is revealed by the data from the tables below, speech therapists consider that specific methods of diagnosis include, in particular, "assessment of realization processes: anatomy of speech organs, motor skills of speech organs, primal activities, assessment of articulators". It is worth noting that also interview and observation are listed as specific methods of speech therapy diagnosis. It is worth stressing that these methods are also characteristic of other disciplines, such as pedagogy, psychology or medicine. It is also disconcerting that only 
one person mentions the examination of language competence as a specific method of speech therapy diagnosis while one person indicates the examination of gross and fine motor skills as a specific method of diagnosis used in logopaedics.

Table 7. Research results concerning the knowledge of specific methods of speech therapy diagnosis

\begin{tabular}{|l|c|c|c|}
\hline \multicolumn{1}{|c|}{$\begin{array}{c}\text { The most frequently listed specific methods of speech therapy } \\
\text { diagnosis }\end{array}$} & Group I & Group II & Total \\
\hline No answer & 8 & 5 & 13 \\
\hline $\begin{array}{l}\text { Assessment of realization processes: anatomy of speech organs, } \\
\text { motor skills of speech organs, primal activities, assessment } \\
\text { of articulators }\end{array}$ & 10 & 8 & 18 \\
\hline Assessment of articulation & 3 & 4 & 7 \\
\hline $\begin{array}{l}\text { Tests (e.g. dictionary tests) and questionnaires (e.g. picture } \\
\text { questionnaires), worksheets of speech therapy examination }\end{array}$ & 3 & 4 & 7 \\
\hline $\begin{array}{l}\text { Assessment of perception processes, e.g. phonetic and phonemic } \\
\text { hearing, auditory analysis and synthesis }\end{array}$ & 2 & 3 & 5 \\
\hline Interview & 2 & 1 & 3 \\
\hline Observation & 2 & 0 & 2 \\
\hline Voice emission & 1 & 0 & 1 \\
\hline Examination of language competence & 0 & 1 & 1 \\
\hline Examination of gross and fine motor skills & 0 & 1 & 1 \\
\hline There are some methods but they are not mentioned & 0 & 1 & 1 \\
\hline There are few of them, especially standardized ones & & & 1 \\
\hline
\end{tabular}

Source: own study based on research.

Table 8 presents answers to the following question "If logopaedics has specific methods of therapy, please give some examples of them". It appears that respondents consider eliciting sounds and consolidating the pronunciation as a specific method of logopaedics. It is also alarming to that some of them consider the use of the trainer, taping and biofeedback to be specific method of logopaedics.

It is difficult to judge on the basis of the research results the factual state of knowledge of speech therapists on selected problems related to the specificity of logopaedics and understanding of its interdisciplinarity. One may, nevertheless, express anxiety connected with different understanding of the subject and aims of logopaedics. I am afraid that some speech therapists understand the interdisciplinarity of logopaedics as using methods non-specific to logopaedics, which means attributing the speech therapist with the right to use methods characteristic of, for instance, orthodontics or physical therapy. This happens when patients are prescribed a trainer or taping. It is also worth paying attention to the number of respondents who did not give any answer to the questions. The reason for not giving any answer remains an open issue: speech therapists either do not know the specific methods of speech therapy diagnosis and therapy or the question is difficult and causes anxiety. 
Table 8. Research results concerning the knowledge of specific methods of speech therapy

\begin{tabular}{|l|c|c|c|}
\hline \multicolumn{1}{|c|}{ Specific methods of speech therapy listed most often } & Group I & Group II & Total \\
\hline No answer & 5 & 5 & 10 \\
\hline Eliciting sounds and consolidating the pronunciation & 8 & 7 & 15 \\
\hline Speech therapy massage, including tongue massage & 4 & 1 & 5 \\
\hline Strategic method of facilitating phoneme realization (SMURF) & 2 & 1 & 3 \\
\hline The Krakow method & 2 & 0 & 2 \\
\hline Exercising the speech organs to learn sounds & 1 & 1 & 2 \\
\hline Trainer & 2 & 0 & 2 \\
\hline Exercising phonetic hearing & 0 & 2 & 2 \\
\hline Augmentative and Alternative Communication (AAC) & 1 & 1 & 2 \\
\hline Exercising primal activities & 2 & 0 & 2 \\
\hline Exercising prosody & 0 & 2 & 2 \\
\hline The glottodidactic method by B. Rocławski & 0 & 1 & 1 \\
\hline Method of beating the rhythm by K. Szamburski & 1 & 0 & 1 \\
\hline Myofunctional therapy & 1 & 0 & 1 \\
\hline Manual sound paving (MTG) & 1 & 0 & 1 \\
\hline Taping & 1 & 0 & 1 \\
\hline Biofeedback & 1 & 0 & 1 \\
\hline $\begin{array}{l}\text { The speech therapist mixes the methods of therapy so as to tailor } \\
\text { them to the patient }\end{array}$ & 0 & 1 & 1 \\
\hline Methods tend to change quickly, they are modified & & & 1 \\
\hline
\end{tabular}

Source: own study based on research.

The subsequent questions of the survey concerned, for example, the quality of cooperation of speech therapists with other specialists. It turns out that speech therapists assess their cooperation with psychologists, educators and physiotherapists as the best whereas collaboration with surgeons (concerning their refusal to cut the lingual frenulum), laryngologists and orthodontists is perceived as the worst. This problem surely requires not only survey research but, most of all, a debate on establishing principles of cooperation and competences of individual specialists connected with the proceedings used in relation to a person with speech disorders.

\section{Conclusion}

Logopaedics is facing a major task connected with ordering the methodology with regard to diagnosis and therapy in order to prevent specialists from annexing somebody else's methods of proceeding since this denotes predatory interdisciplinarity. It is also important to see the well-being of the patient who is recommended, e.g. a trainer by the speech therapist. Prescribing this appliance is the domain and competence of the orthodontist rather than the speech therapist. Polish logopaedics should also strive to order the educational process of future speech therapists 
which is not homogenous in our country, bearing in mind the curriculum content. Elaborating educational standards is an urgent task which should become a subject of concern for speech therapists.

Another task is connected with the discussion with specialists who the speech therapist cooperates with: orthodontists, pediatricians, laryngologists, surgeons, physiotherapists, neurologists, educators and psychologists. It is difficult, though, to initiate discussion with those specialists if we do not agree on the major tasks and role of the speech therapist in multi-specialist assistance to a person with speech disorders.

Elżbieta Chrzanowska-Kluczewska is right with regard to the problem of interdisciplinarity of logopaedics, saying that: "[...] if contemporary scientists from remote disciplines do not make an effort to go beyond their own universe, they will be like those parallel worlds or lonely Leibniz's monads closed in their own hermetic shell" [Chrzanowska-Kluczewska, 2007, p. 23].

Finding balance between intradisciplinary research and interdisciplinary research is necessary for the development of logopaedics. Each of these approaches performs a different role in building the independence of logopaedics, going beyond the limitations of intradisciplinary research and building a research field, perhaps in the spirit of transdisciplinarity [Michalik, 2015]. "Intradisciplinary research" and "research going beyond its own limitations" are equally useful yet it is also important to maintain harmony and balance between these two approaches.

Mirosław Michalik [2015] sees the future of logopaedics as a transdisciplinarity science. This is an important methodological project. Yet it is difficult to build transdisciplinarity if there is such a diversity of approaches to the same subject in Polish logopaedics. An adversary to this approach would say diversity fosters the development of science yet some proposed perspectives of examination, description and therapy of speech disorders are contradictory, e.g. with regard to the approach to research and description of phoneme realization disorders. Hence it is important to present different rather than selective approaches to the same issue during the educational process. Showing the student the factual state of Polish reflection on the given speech disorder becomes a cognitive tool for the young speech therapist which will enable him to choose his own scientific path and/or practical development. 


\section{References}

Chrzanowska-Kluczewska E., 2007, Konsiliencja, czyli o porozumieniu między naukami w trzecim tysiącleciu, [in:] G. Szpila (ed.), Język polski XXI wieku: analizy, oceny, perspektywy, monografia z cyklu Język trzeciego tysiąclecia, Kraków: Tertium, pp. 15-23.

Dubisz S. (ed.), 2004, Uniwersalny słownik jezzyka polskiego, electronic version, Warszawa: Wydawnictwo Naukowe PWN.

Grabias S., 1997, Mowa i jej zaburzenia, "Audiofonologia”, vol. 10, pp. 3-20.

Grabias S., 2008, Postępowanie logopedyczne. Diagnoza, programowanie terapii, terapia, "Logopedia", no. 37, pp. 13-27.

Grabias S., 2012, Teoria zaburzeń mowy. Perspektywy badań, typologie zaburzeń, procedury postępowania logopedycznego, [in:] S. Grabias, M. Kurkowski (eds.), Logopedia. Teoria zaburzeń mowy, Lublin: Wydawnictwo Uniwersytetu Marii Curie-Skłodowskiej, pp. 15-71.

Grabias S., 2015, Postępowanie logopedyczne. Standardy terapii, [in:] S. Grabias, J. Panasiuk. T. Woźniak (eds.), Logopedia. Standardy postępowania logopedycznego. Podręcznik akademicki, Lublin: Wydawnictwo Uniwersytetu Marii Curie-Skłodowskiej, pp. 13-38.

Kita M., 2012, "Razem". Konsiliencja, interdyscyplinarność, transdyscyplinarność, [in:] M. Kita, M. Ślawska (eds.), Transdyscyplinarność badań nad komunikacją medialną. T. 1: Stan wiedzy i postulaty badawcze, Katowice: Wydawnictwo Uniwersytetu Śląskiego, pp. 11-30.

Koczanowicz L., 2011, Interdyscyplinarność między rabunkiem a dialogiem, [in:] R. Włodarczyk, W. Żłobicki (eds.), Interdyscyplinarność i transdyscyplinarność pedagogiki - wymiary praktyczny i teoretyczny, Kraków: Oficyna Wydawnicza Impuls, pp. 35-43.

Łuczyński E., 2011, Rozgryzając tajniki mowy. Wiedza o języku polskim dla logopedów, Gdańsk: Wydawnictwo Uniwersytetu Gdańskiego.

Michalik M., 2015, Transdyscyplinarność logopedii - między metodologiczną koniecznościa a teoretyczna utopią, [in:] S. Milewski, K. Kaczorowska-Bray (eds.), Metodologia badań logopedycznych z perspektywy teorii i praktyki, Gdańsk: Harmonia Universalis, pp. 32-46.

Pluta-Wojciechowska D., 2019, Między lingwistyka a medycyna, [in:] D. Pluta-Wojciechowska, Efektywność terapii dyslalii. Logopedyczno-lingwistyczna analiza wyników badań, Katowice: Wydawnictwo Uniwersytetu Śląskiego, pp. 21-37.

Porayski-Pomsta J., 2013, Logopedia w społeczeństwie komunikacyjnym, [in:] Z. Zaro, J. PorayskiPomsta (eds.), Język i logopedia, Warszawa: Wydział Polonistyki Uniwersytetu Warszawskiego, pp. 141-147.

Słownik języka polskiego PWN, https://sjp.pwn.pl/sjp/interdyscyplinarny.;2466577 (accessed: 9.12.2019). 


\section{Abstract}

The author presents considerations on logopaedics as a science, exposing the interdisciplinary character of this discipline. The problem discussed in the paper is depicted in the context of two processes observed in science, namely dividing and combining knowledge. Against this background the author analyzes the subject and tasks of logopaedics, taking into account linguistics, pedagogy and psychology. She also presents preliminary results of survey research concerning the understanding by speech therapists of the interdisciplinarity of logopaedics, the specific nature of diagnosis and therapy methods which, in the opinion of respondents, are specific to logopaedics. She also points to the major tasks of logopaedics which are connected with ordering the methodology of proceeding and the education process.

\section{Streszczenie}

Autorka przedstawia rozważania na temat logopedii jako nauki, eksponując jej interdyscyplinarność. Podejmowany w tekście problem przedstawia w kontekście dwu procesów obserwowanych w nauce, a mianowicie dzielenia i jednoczenia wiedzy. Na tym tle analizuje przedmiot i zadania logopedii, biorąc pod uwagę lingwistykę, medycynę, pedagogikę i psychologię. Przedstawia także wstępne wyniki badań ankietowych, które dotyczyły rozumienia przez logopedów interdyscyplinarności logopedii, specyfiki metod diagnozy i terapii, jakie - w opinii respondentów - są charakterystyczne dla logopedii. Wskazuje również najważniejsze zadania logopedii, które wiążą się z uporządkowaniem metodologii i metodyki postępowania, a także kształcenia. 